Article

\title{
A Novel Gelatinase from Marine Flocculibacter collagenilyticus SM1988: Characterization and Potential Application in Collagen Oligopeptide-Rich Hydrolysate Preparation
}

\author{
Jian Li ${ }^{1,2}{ }^{2}$, Jun-Hui Cheng ${ }^{2}$, Zhao-Jie Teng ${ }^{2}$, Xia Zhang ${ }^{3}$, Xiu-Lan Chen ${ }^{2}$, Mei-Ling Sun ${ }^{4}$, Jing-Ping Wang ${ }^{2}$, \\ Yu-Zhong Zhang ${ }^{4}$, Jun-Mei Ding ${ }^{5, *}$, Xin-Min Tian ${ }^{1, *}$ and Xi-Ying Zhang ${ }^{2, *}$
}

check for updates

Citation: Li, J.; Cheng, J.-H.; Teng, Z.-J.; Zhang, X.; Chen, X.-L.; Sun, M.-L.; Wang, J.-P.; Zhang, Y.-Z.; Ding, J.-M.; Tian, X.-M.; et al. A Novel Gelatinase from Marine Flocculibacter collagenilyticus SM1988:

Characterization and Potential Application in Collagen Oligopeptide-Rich Hydrolysate Preparation. Mar. Drugs 2022, 20, 48. https://doi.org/10.3390/ md20010048

Academic Editor: Sik Yoon

Received: 6 December 2021

Accepted: 30 December 2021

Published: 3 January 2022

Publisher's Note: MDPI stays neutral with regard to jurisdictional claims in published maps and institutional affiliations.

Copyright: (C) 2022 by the authors. Licensee MDPI, Basel, Switzerland. This article is an open access article distributed under the terms and conditions of the Creative Commons Attribution (CC BY) license (https:// creativecommons.org/licenses/by/ $4.0 /)$.
1 Xinjiang Key Laboratory of Biological Resources and Genetic Engineering, College of Life Science and Technology, Xinjiang University, Urumqi 830046, China; fighter1216217564@163.com

2 State Key Laboratory of Microbial Technology, Marine Biotechnology Research Center, Institute of Marine Science and Technology, Shandong University, Qingdao 250100, China; 201820299@mail.sdu.edu.cn (J.-H.C.); tengpaper@163.com (Z.-J.T.); cx10423@sdu.edu.cn (X.-L.C.); jp1120714999@163.com (J.-P.W.)

3 Department of Molecular Biology, Qingdao Vland Biotech Inc., Qingdao 266102, China; zhangx@vlandgroup.com

4 College of Marine Life Sciences, and Frontiers Science Center for Deep Ocean Multispheres and Earth System, Ocean University of China, Qingdao 266003, China; sunml1990@yeah.net (M.-L.S.); zhangyz@sdu.edu.cn (Y.-Z.Z.)

5 Engineering Research Center of Sustainable Development and Utilization of Biomass Energy, Ministry of Education, Yunnan Normal University, Kunming 650500, China

* Correspondence: djm3417@163.com (J.-M.D.); tianxm06@lzu.edu.cn (X.-M.T.); zhangxiying@sdu.edu.cn (X.-Y.Z.)

\begin{abstract}
Although the S8 family in the MEROPS database contains many peptidases, only a few S8 peptidases have been applied in the preparation of bioactive oligopeptides. Bovine bone collagen is a good source for preparing collagen oligopeptides, but has been so far rarely applied in collagen peptide preparation. Here, we characterized a novel S8 gelatinase, Aa2_1884, from marine bacterium Flocculibacter collagenilyticus SM1988 ${ }^{\mathrm{T}}$, and evaluated its potential application in the preparation of collagen oligopeptides from bovine bone collagen. Aa2_1884 is a multimodular S8 peptidase with a distinct domain architecture from other reported peptidases. The recombinant Aa2_1884 over-expressed in Escherichia coli showed high activity toward gelatin and denatured collagens, but no activity toward natural collagens, indicating that Aa2_1884 is a gelatinase. To evaluate the potential of Aa2_1884 in the preparation of collagen oligopeptides from bovine bone collagen, three enzymatic hydrolysis parameters, hydrolysis temperature, hydrolysis time and enzyme-substrate ratio $(\mathrm{E} / \mathrm{S})$, were optimized by single factor experiments, and the optimal hydrolysis conditions were determined to be reaction at $60{ }^{\circ} \mathrm{C}$ for $3 \mathrm{~h}$ with an $\mathrm{E} / \mathrm{S}$ of $400 \mathrm{U} / \mathrm{g}$. Under these conditions, the hydrolysis efficiency of bovine bone collagen by Aa2_1884 reached 95.3\%. The resultant hydrolysate contained $97.8 \%$ peptides, in which peptides with a molecular weight lower than $1000 \mathrm{Da}$ and $500 \mathrm{Da}$ accounted for $55.1 \%$ and $39.5 \%$, respectively, indicating that the hydrolysate was rich in oligopeptides. These results indicate that Aa2_1884 likely has a promising potential application in the preparation of collagen oligopeptide-rich hydrolysate from bovine bone collagen, which may provide a feasible way for the high-value utilization of bovine bone collagen.
\end{abstract}

Keywords: peptidase; the MEROPS S8 family; bovine bone collagen; oligopeptides; hydrolysate

\section{Introduction}

Bioactive oligopeptides are referred to peptides that consist of 2-20 amino acids, which have various bioactivities [1]. In addition to being efficient amino acid sources, bioactive oligopeptides have been reported to possess many physiological functions and attractive 
physic properties in pharmacy (e.g., anticancer, antimicrobial, antihypertensive and antiinflammatory activities, anticoagulant, and immunomodulatory), foods (gelling activity and emulsifying property), cosmetic (antioxidant and water holding capacity), and other functional products (foaming ability and hydrophobicity) [2-5]. In recent years, collagen oligopeptides attract more and more attention due to their various bioactive properties, such as angiotensin I converting enzyme (ACE) inhibitory activity, antioxidant activity, immunomodulatory and antimicrobial activities [6-9], and beneficial effects on human health, including improving skin health, muscle strength, and bone density [10-12], and reducing obesity, joint pain, and blood pressure [13-15]. Collagen oligopeptides have been widely applied in food, cosmetics, healthcare, and pharmaceutical industries [16-18].

Enzymatic hydrolysis is now the common method to prepare collagen bioactive peptides from collagen-rich animal tissues, such as skin, bones, tendons, and ligaments. Nowadays, the common enzymes for preparing collagen bioactive peptides are proteases from plants, animals, and bacteria, such as serine proteases alcalase of the MEROPS S8 family and trypsin and $\alpha$-chymotrypsin of the MEROPS S1 family, aspartic protease pepsin of the MEROPS A1 family, cysteine protease papain of the MEROPS C1 family, and metalloprotease thermolysin of the MEROPS M4 family [6,19-22]. The S8 family is the second largest family of serine proteases after the S1 family [23]. In the S8 family, many members have activity on gelatin, the denatured form of collagen, and some are collagenolytic proteases, such as the thermostable protease from Geobacillus collagenovorans MO-1 [24], MCP-01 from Pseudoalteromonas sp. SM9913 [25], myroicolsin from Myroides profundi D25 [26], and P57 from Photobacterium sp. A5-7 [27]. Due to their activity on natural or denatured collagen, these $\mathrm{S} 8$ peptidases may have potentials in collagen oligopeptide preparation. However, only a few S8 peptidases have been used in preparing collagen oligopeptides, or their potentials have been evaluated. In addition to alcalase that are from Bacillus and have been used in collagen oligopeptide preparation [28], MCP-01 has also been shown to have a potential in preparing collagen bioactive peptides from codfish skin [7]. It is still necessary to identify more $\mathrm{S} 8$ peptidases suitable for preparing collagen bioactive peptides.

Recently, we isolated and identified a novel marine bacterium Flocculibacter collagenilyticus SM1988 ${ }^{\mathrm{T}}$ (hereafter SM1988) that has a high collagenase production [29]. According to the genome and secretome analyses of this strain, Aa2_1884 was the most abundant of the 6 secreted S8 proteases and was predicted to be a potential collagenase [29]. The aim of this study was to characterize Aa2_1884 and to evaluate its potential in preparing collagen bioactive peptides. In this study, Aa2_1884 was expressed in Escherichia coli and biochemically characterized. The potential of Aa2_1884 in preparing collagen oligopeptides from bovine bone collagen was further evaluated. The results indicate that Aa2_1884 is a novel multimodular gelatinase with a good potential in preparing collagen oligopeptide from bovine bone collagen.

\section{Results and Discussion}

\subsection{Aa2_1884 Is a Novel Multimodular Peptidase of the S8 Family}

The amino acid sequence of protein Aa2_1884 (WP_199608745.1) deduced from the genome of strain SM1988 is composed of 1135 amino acid residues, containing a signal peptide with a length of 34 amino acid residues at the N terminus based on the SignalP 5.0 prediction. Aa2_1884 is annotated as an S8 family serine peptidase by BLASTP through the non-redundant protein database. InterProScan analysis indicated that, in addition to the predicted signal peptide, Aa2_1884 has five conserved domains (Figure 1), including an inhibitor I9 domain (Tyr72-Thr175, IPR010259), a peptidase S8 domain (Gly209-Lys661, IPR000209), a protease associated (PA) domain (Ser466-Leu545, IPR003137), a fibronectin type-III (FN3) domain (Leu711-Arg790, IPR041469), and a domain of unknown function (DUF11) (Lys817-Val863, IPR001434). The inhibitor I9 domain likely functions as a molecular chaperone to assist the protein folding of Aa2_1884 [30,31]. The peptidase S8 domain is the catalytic domain, containing the characteristic catalytic triad of the S8 family, namely 
Asp218, His287, and Ser622 (Figure 2). The PA domain is an inserted domain in the peptidase S8 domain, which has been shown to play a role in collagen binding in some S8 proteases [27,32]. FN3 domain has been found in several proteases [33,34], whose function in proteases, however, has not been revealed. DUF11 domain is also present in peptidase brachyurin-T of the S1 family from Caldilinea aerophile based on InterProScan prediction (Figure 1). However, its function in peptidases such as brachyurin-T and Aa2_1884 needs further study.

Aa2_1884 (Flocculibacter collagenilyticus SM1988)

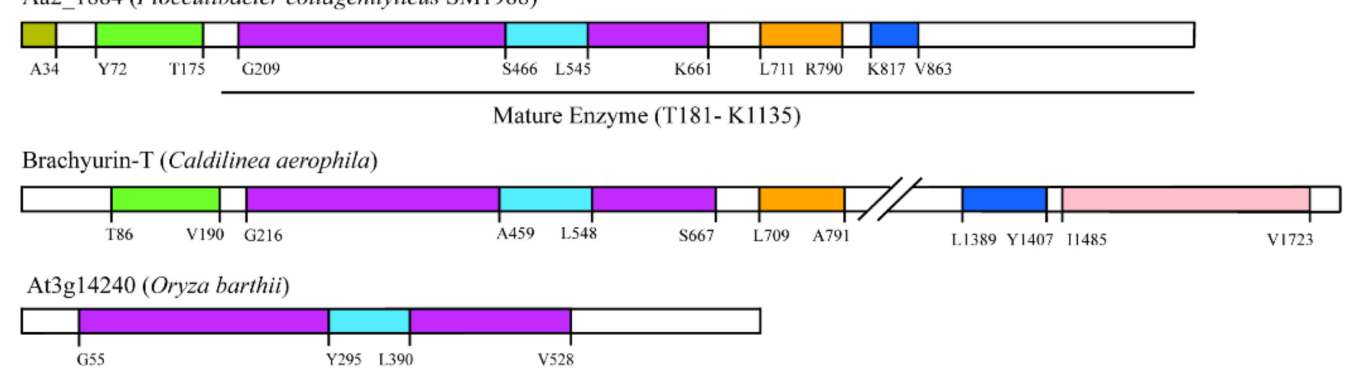

MO-1 (Geobacillus sp. MO-1)

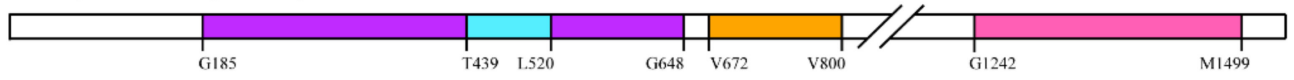

MCP-01 (Pseudoalteromonas sp. SM9913)

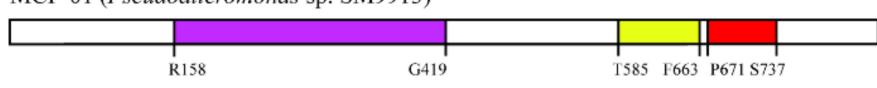

Myroicolsin (Myroides profundi D25)

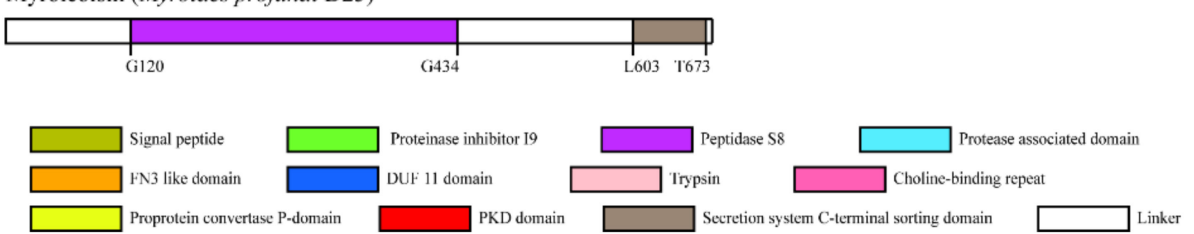

Figure 1. Domain architectures of Aa2_1884 and similar proteases predicted by InterPro. Marked numbers show the corresponding position of predicted domains in the amino acid sequences of the proteases.

Among the characterized peptidases, Aa2_1884 shares the highest sequence identity $(44.05 \%)$ with brachyurin-T of the S1 family [35]. It is also most close to brachyurin-T in the phylogenetic tree (Figure 3). However, the domain architectures of these two enzymes are different. Compared to brachyurin-T, Aa2_1884 lacks the C-terminal Trypsin domain (Figure 1). Among all the characterized peptidases, none were found to have the same domain architecture as Aa2_1884 (Figure 1). These data suggest that Aa2_1884 is a novel multimodular protease of the S8 family. In addition, as shown in Figure 2, sequence alignment indicated that Aa2_1884 contains several motifs that are conserved in reported S8 collagenases, which suggests that Aa2_1884 may have collagenolytic activity. 


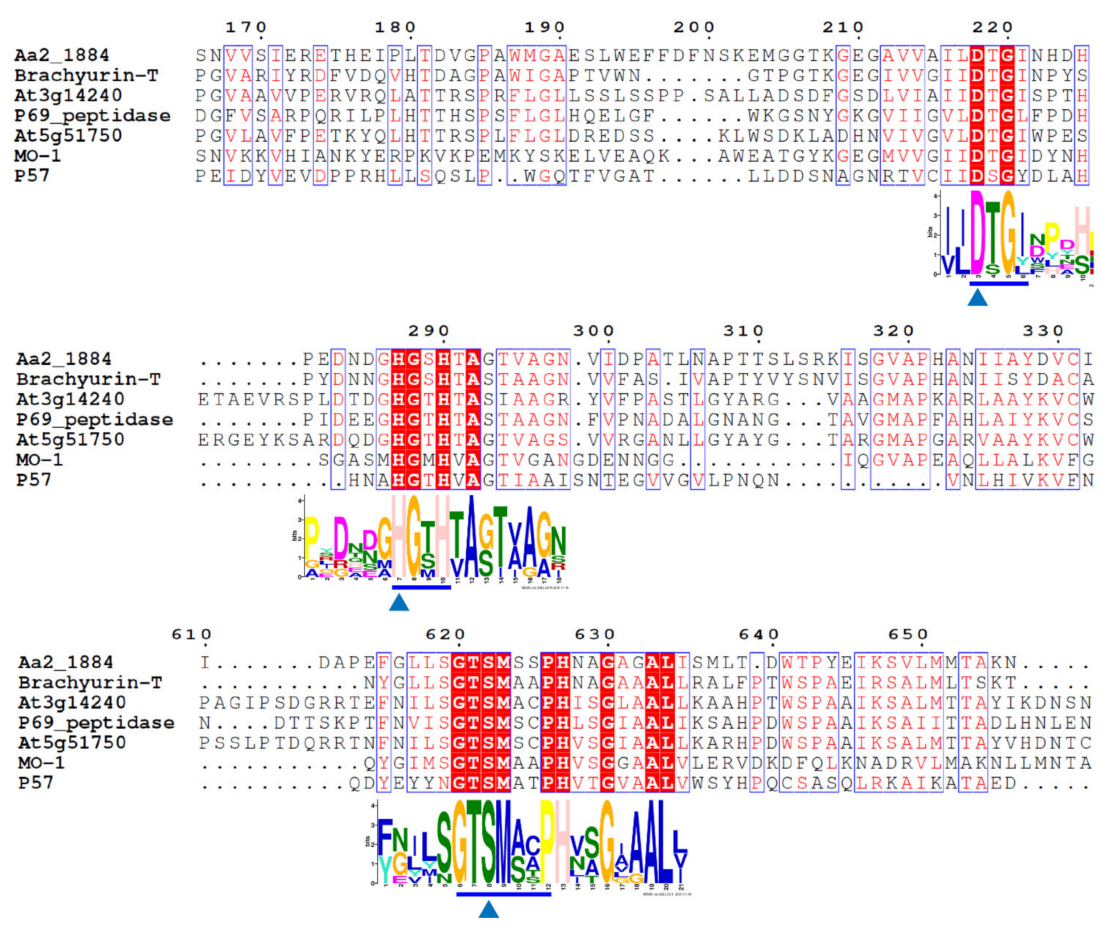

Figure 2. Sequence alignment of Aa2_1884 with similar proteases and reported S8 collagenases using the ClustalW program. Similar amino acid residues are boxed and shown in red, conserved amino acid residues are shown with red background. Amino acid residues constituting the catalytic triad of the MEROPS 88 family are marked with blue triangles, and motifs containing these residues are marked with blue underlines. Aa2_1884 (WP_199608745) is from Flocculibacter collagenilyticus SM1988, brachyurin-T (YP_005442656) from Caldilinea aerophile, At3g14240 (MER0006049) from Oryza barthii, P69 peptidase (XP_002275452) from Vitis vinifera, At5g51750 (XP_009789180) from Nicotiana sylvestris, MO-1 (BAF30978) from Geobacillus sp. MO-1, and P57 (KT923662) protease from Photobacterium sp. A5-7.

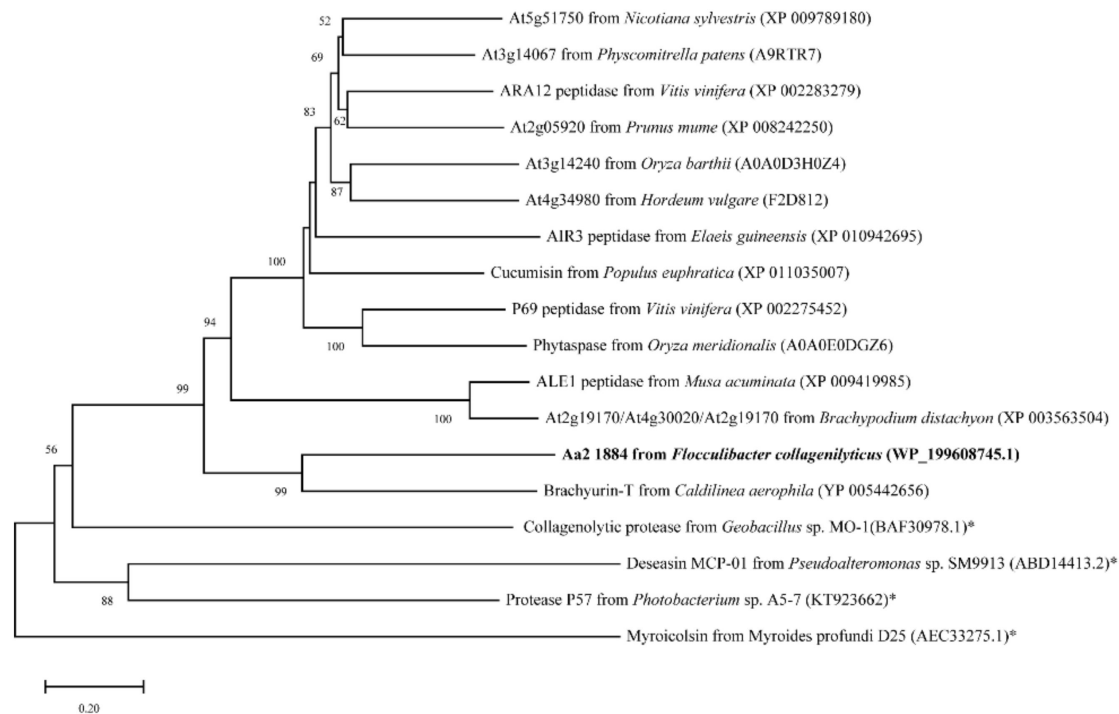

Figure 3. Neighbor-joining (NJ) phylogenetic tree based on amino acid sequences of Aa2_1884 and similar proteases. The tree was constructed with MEGA X. Bootstrap values $(>50 \%)$ based on 1000 replicates were presented at nodes. Bar, 0.20 . The reported S8 collagenases are indicated by asterisks. 


\subsection{Aa2_1884 Is a Gelatinase with High Activity toward Denatured Collagens}

To characterize Aa2_1884, the gene of Aa2_1884 was over-expressed in Escherichia coli BL21 (DE3) with the vector pET-22b (+) containing a C-terminal His tag. The recombinant Aa2_1884 protein was purified by affinity chromatography on a His Bind Ni chelating column and gel filtration chromatography on a Sephadex G200 column. Sodium dodecyl sulfate polyacrylamide gel electrophoresis (SDS-PAGE) analysis showed that the purified Aa2_1884 had an apparent molecular weight of approximately 100,000 Da (Figure 4a). The N-terminal sequence of the purified Aa2_1884 was determined to T181-D-V-G-P-A186 by $\mathrm{N}$-terminal sequencing. Thus, on the basis of its $\mathrm{N}$-terminal sequence and molecular weight, mature Aa2_1884 should contain 955 amino acid residues from Thr181 to Lys1135 (Figure 1). The signal peptide and the inhibitor I9 domain are cleaved off during maturation.

(a)
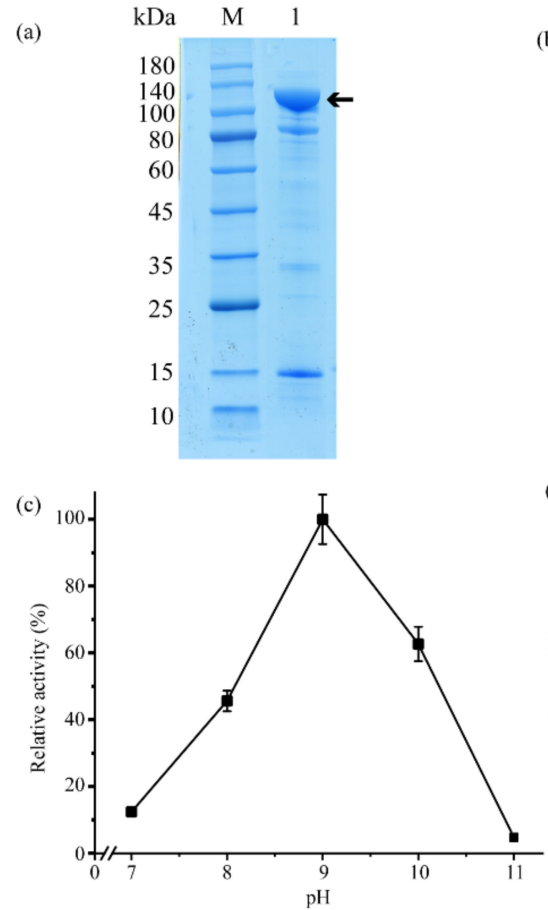

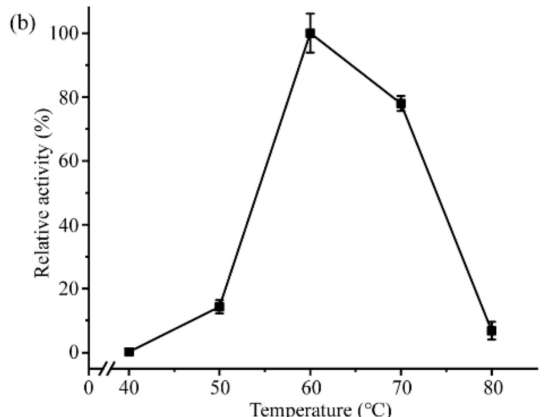

(d)

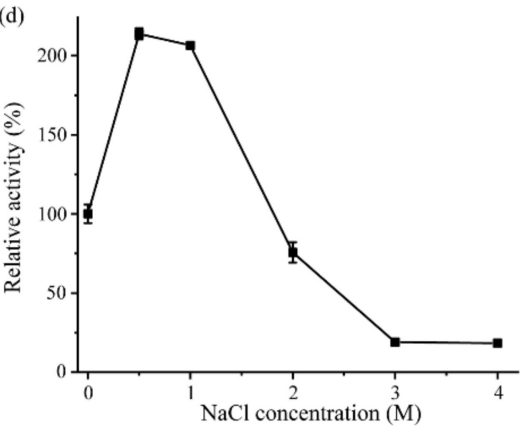

Figure 4. Purification and characterization of Aa2_1884: (a) SDS-PAGE analysis of purified Aa2_1884. Lane M, protein mass markers. Lane 1, purified Aa2_1884. The protein band of Aa2_1884 is indicated by an arrow; (b) Effect of temperature on the activity of Aa2_1884. The experiment was performed in Tris- $\mathrm{HCl}$ buffer $(50 \mathrm{mM}, \mathrm{pH} 9.0)$ at $40-80{ }^{\circ} \mathrm{C}$, and the enzyme activity at $60{ }^{\circ} \mathrm{C}$ was taken as $100 \%$; (c) Effect of $\mathrm{pH}$ on the activity of Aa2_1884. The enzyme activity was measured at $60{ }^{\circ} \mathrm{C}$ with $40 \mathrm{mM}$ Britton-Robinson buffers ranged from $\mathrm{pH} 7$ to $\mathrm{pH} 11$. The enzyme activity at $\mathrm{pH} 9.0$ was taken as $100 \%$; (d) Effect of $\mathrm{NaCl}$ concentration on the activity of Aa2_1884. The activity was measured at $60{ }^{\circ} \mathrm{C}$ in Tris- $\mathrm{HCl}$ buffer $(50 \mathrm{mM}, \mathrm{pH} 9.0)$ containing different concentrations of $\mathrm{NaCl}$ from 0 to $4 \mathrm{M}$. The enzyme activity in the Tris- $\mathrm{HCl}$ buffer with $0 \mathrm{M} \mathrm{NaCl}$ was taken as $100 \%$. In (b-d), bovine bone collagen was used as the substrate in the experiments. The graphs show data from triplicate experiments (mean $\pm \mathrm{SD}$ ).

Sequence alignment implied that Aa2_1884 may have collagenolytic activity. Indeed, Aa2_1884 had noticeable activity towards bovine bone collagen at temperatures of $50-70{ }^{\circ} \mathrm{C}$, with an optimal temperature at $60^{\circ} \mathrm{C}$. However, it had almost no activity towards bovine bone collagen at $40{ }^{\circ} \mathrm{C}$ (Figure 4b). At $60{ }^{\circ} \mathrm{C}$, Aa2_1884 also had activity towards bovine tendon collagen, gelatin, and casein, but no activity toward elastin-orcein (Table 1). As collagen is denatured at temperatures more than $40^{\circ} \mathrm{C}$, these results indicate that Aa2_1884 can hydrolyze denatured collagen, but not natural collagen. Therefore, Aa2_1884 is a gelatinase, rather than a collagenase. With bovine bone collagen as the substrate, Aa2_1884 showed the highest activity at $\mathrm{pH} 9.0$ (Figure 4c), indicating that it is an alkaline protease. 
In the buffer containing different $\mathrm{NaCl}(0-4 \mathrm{M}), \mathrm{Aa} 2 \_1884$ showed the highest activity at 0.5-1 M NaCl (Figure 4d). These characteristics reflect the adaptation of Aa2_1884 to the marine salty and alkaline environment.

Table 1. The substrate specificity of Aa2_1884 ${ }^{\$}$.

\begin{tabular}{cc}
\hline Substrate & Enzymatic Activity (U/mL) \\
\hline Bovine bone collagen & $801.15 \pm 46.45$ \\
Bovine tendon collagen & $761.27 \pm 43.41$ \\
Gelatin & $834.00 \pm 61.39$ \\
Casein & $51.75 \pm 1.85$ \\
Elastin-orcein & - \\
\hline
\end{tabular}

$\$$ The activities of Aa2_1884 towards different substrates were measured in Tris- $\mathrm{HCl}(50 \mathrm{mM}, \mathrm{pH} 9.0)$ at $60{ }^{\circ} \mathrm{C}$. The data represent the mean $\pm \mathrm{SD}$ of three experimental repeats.

We also analyzed the effects of metal ions and protease inhibitors on the activity of Aa2_1884. As shown in Table 2, $\mathrm{Ca}^{2+}, \mathrm{Ba}^{2+}, \mathrm{Sr}^{2+}$, and $\mathrm{Mg}^{2+}$ significantly increased the activity of Aa2_1884 towards bovine bone collagen, $\mathrm{Zn}^{2+}$ and $\mathrm{Fe}^{2+}$ severely inhibited its activity, and $\mathrm{Ni}^{2+}, \mathrm{Co}^{2+}$, and $\mathrm{Mn}^{2+}$ completely inhibited its activity (Table 2). Surprisingly, none of the four tested inhibitors, phenylmethylsulfonyl fluoride (PMSF), ethylenediamine tetraacetic acid (EDTA), ethylene glycol tetraacetic acid (EGTA), or o-phenanthroline (o-P), had inhibitory effect on the activity of Aa2_1884 (Figure 5), which is an unusual phenomenon for an S8 peptidase. Among these inhibitors, PSMF is a classical inhibitor to serine proteases, however, there are also some exceptions. Kexin has been reported to be resistant to PMSF [36]. Kexin is a typical S8 peptidase produced by Saccharomyces cerevisiae, which contains 814 amino acid residues. Different from Aa2_1884, Kexin contains only a P-proprotein domain in addition to the Peptidase S8 domain [37]. It still remains elusive why kexin is resistant to PMSF. Thus, the underlying mechanisms of kexin and Aa2_1884 to resist PMSF need further investigation.

Table 2. Effects of metal ions on the activity of Aa2_1884 a .

\begin{tabular}{|c|c|c|c|c|c|}
\hline \multirow{2}{*}{ Metal Ion } & \multicolumn{2}{|c|}{ Relative Activity (\%) } & \multirow{2}{*}{ Metal Ion } & \multicolumn{2}{|c|}{ Relative Activity (\%) } \\
\hline & $2 \mathrm{mM}$ & $4 \mathrm{mM}$ & & $2 \mathrm{mM}$ & $4 \mathrm{mM}$ \\
\hline Control & 100 & 100 & $\mathrm{~K}^{+}$ & $108.62 \pm 8.24$ & $116.60 \pm 4.18$ \\
\hline $\mathrm{Ca}^{2+}$ & $263.67 \pm 7.06$ & $251.90 \pm 10.14$ & $\mathrm{Sn}^{2+}$ & $97.01 \pm 0.12$ & $100.32 \pm 4.40$ \\
\hline $\mathrm{Ba}^{2+}$ & $250.54 \pm 11.34$ & $276.80 \pm 10.14$ & $\mathrm{Zn}^{2+}$ & $56.50 \pm 2.99$ & $40.69 \pm 1.33$ \\
\hline $\mathrm{Sr}^{2+}$ & $245.91 \pm 6.45$ & $210.87 \pm 29.18$ & $\mathrm{Fe}^{2+}$ & $43.73 \pm 4.78$ & $5.05 \pm 2.04$ \\
\hline $\mathrm{Mg}^{2+}$ & $217.58 \pm 7.25$ & $217.25 \pm 32.74$ & $\mathrm{Ni}^{2+}$ & $-b$ & - \\
\hline $\mathrm{Li}^{+}$ & $111.41 \pm 4.40$ & $116.60 \pm 4.18$ & $\mathrm{Co}^{2+}$ & - & - \\
\hline $\mathrm{Cu}^{2+}$ & $100.32 \pm 2.96$ & $122.83 \pm 2.43$ & $\mathrm{Mn}^{2+}$ & - & - \\
\hline
\end{tabular}

a The activity of Aa2_1884 was measured in Tris- $\mathrm{HCl}\left(50 \mathrm{mM}, \mathrm{pH} \mathrm{9.0)}\right.$ at $60^{\circ} \mathrm{C}$ with bovine bone collagen as the substrate. The activity $(657.37 \mathrm{U} / \mathrm{mL})$ without any metal ion was used as a control $(100 \%)$. The data represent the mean \pm SD of three experimental repeats. ${ }^{b}$ " $-"$ means that enzyme activity was not detectable.

The S8 family, the second largest family of serine peptidases, contains more than 200 peptidases in the MEROPS database (https: / / www.ebi.ac.uk/merops / cgi-bin/famsum? family $=S 8$, accessed on 6 December 2021). In this family, only a small number have collagenolytic activity, but many have gelatinolytic activity. Different from those with collagenolytic activity, Aa2_1884 has no activity towards native collagen. On the other hand, although Aa2_1884 has gelatinolytic activity, it has a distinct domain architecture and is resistant to PMSF, compared to those with gelatinolytic activity in the S8 family. Therefore, Aa2_1884 is a new gelatinase of the S8 family. The S8 family includes diverse peptidases produced by bacteria, archaea, and eukaryotes from various environments, and most are secreted endopeptidases. Therefore, both the temperature and $\mathrm{pH}$ optima of the S8 peptidases are in a wide range due to the adaptation of the peptidases to their respective environments [38]. For example, assays of subtilisins from Bacillus species are typically performed at $\mathrm{pH} 8.2-8.6$ and $25^{\circ} \mathrm{C}$ [39]. The $\mathrm{pH}$ optima of the S8 peptidases from 
archaea are usually in the range of 7.5-10.7, and their temperature optima are in a wide range of $55-115^{\circ} \mathrm{C}$ [40]. The $\mathrm{pH}$ optima of the $\mathrm{S} 8$ collagenases from bacteria are within the range of 7.1-9.3, and their temperature optima are usually $50-60{ }^{\circ} \mathrm{C}[24,26,41,42]$. The optimal temperature and $\mathrm{pH}$ of Aa2_1884 are $60^{\circ} \mathrm{C}$ and $\mathrm{pH}$ 9.0, which fall in the optimal temperature and $\mathrm{pH}$ ranges of the $\mathrm{S} 8$ peptidases.

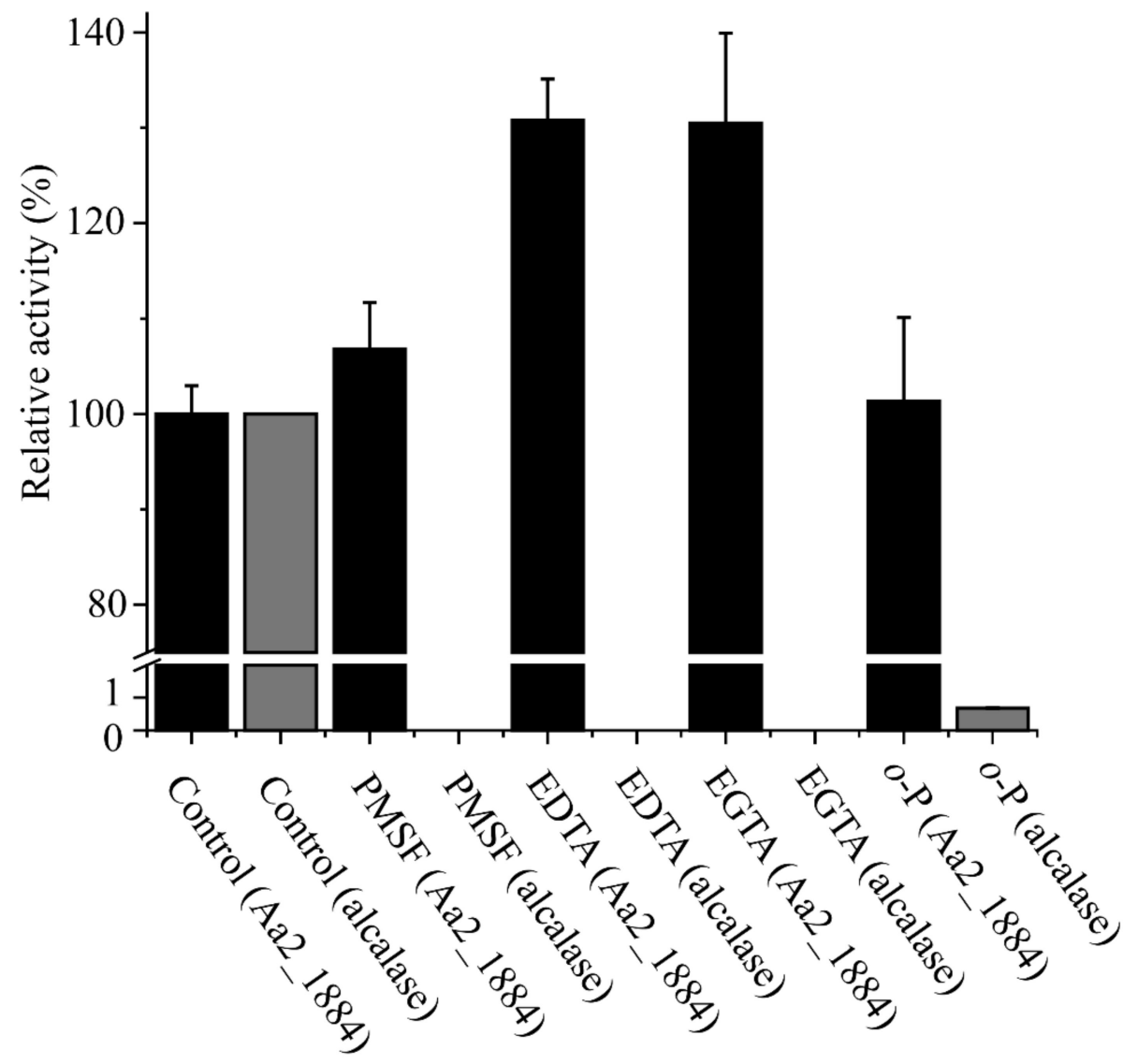

Figure 5. Effects of protease inhibitors on the activity of Aa2_1884. Aa2_1884 and the control enzyme alcalase were incubated at $4{ }^{\circ} \mathrm{C}$ for $1 \mathrm{~h}$ in $50 \mathrm{mM}$ Tris- $\mathrm{HCl}$ ( $\mathrm{pH}$ 9.0) containing $2 \mathrm{mM}$ of each inhibitor, PMSF, EDTA, EGTA, or o-P. After incubation, the residual activity toward bovine bone collagen was measured at $60{ }^{\circ} \mathrm{C}, \mathrm{pH} 9.0$. The activity of Aa2_1884 without any inhibitor was taken as $100 \%$. The graphs show data from triplicate experiments (mean $\pm \mathrm{SD}$ ).

\subsection{Aa2_1884 Shows High Hydrolytic Efficiency on Bovine Bone Collagen}

As Aa2_1884 had high activity towards bovine bone collagen at $60^{\circ} \mathrm{C}$ (Figure $4 \mathrm{~b}$ ), it may have a potential in preparing collagen bioactive peptides from bovine bone collagen. Thus, attempts were made to prepare peptides from bovine bone collagen with Aa2_1884 as a tool. To determine the optimal hydrolysis conditions, three enzymatic hydrolysis parameters were optimized by single factor experiments, including hydrolysis temperature, hydrolysis time and enzyme-substrate ratio (E/S). On the basis of the residual amount of collagen, the appropriate hydrolysis temperature and time of Aa2_1884 were determined to be $55-65{ }^{\circ} \mathrm{C}$ (Figure 6a) and $\geq 3 \mathrm{~h}$ (Figure 6b), respectively. When the E/S was more than $400 \mathrm{U} / \mathrm{g}$, no more obvious decrease in the amount of residual collagen was detected (Figure 6c). Hence, considering the hydrolysis efficiency and economic benefit, the optimal conditions of Aa2_1884 for the hydrolysis of bovine bone collagen on the laboratory scale were determined to be reaction at $60^{\circ} \mathrm{C}$ for $3 \mathrm{~h}$ with an $\mathrm{E} / \mathrm{S}$ ratio of $400 \mathrm{U} / \mathrm{g}$. Under these hydrolysis conditions, the maximum hydrolytic efficiency of bovine bone collagen reached $95.3 \pm 0.3 \%$, indicating that Aa2_1884 is a good enzyme for the hydrolysis of bovine bone 
collagen. We then prepared bovine bone collagen hydrolysate with Aa2_1884 under the determined hydrolysis conditions.
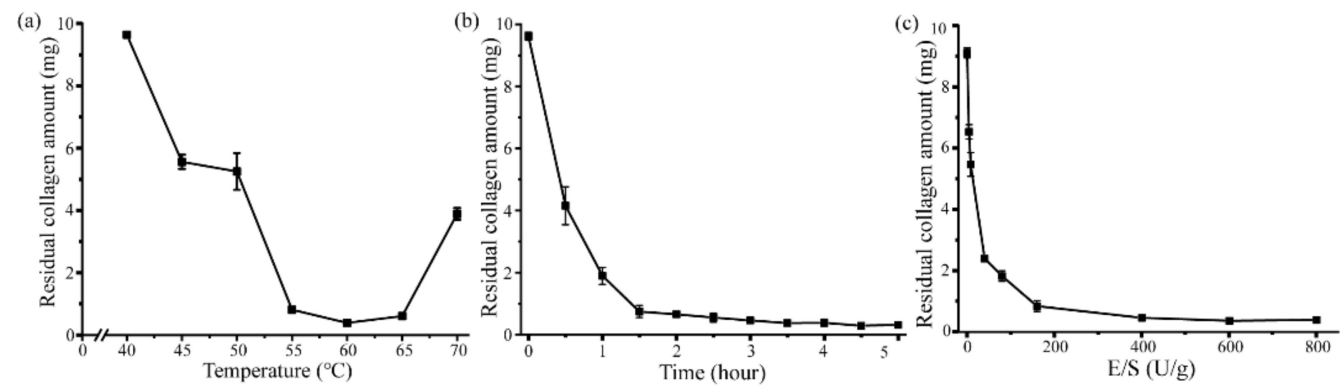

Figure 6. Effects of temperature, time and E/S on the hydrolysis efficiency of bovine bone collagen: (a) Effect of hydrolysis temperature determined at the hydrolysis time of $3 \mathrm{~h}$ and the hydrolysis E/S of $400 \mathrm{U} / \mathrm{g}$; (b) Effect of hydrolysis time determined at the hydrolysis temperature of $60{ }^{\circ} \mathrm{C}$ and the hydrolysis E/S of $400 \mathrm{U} / \mathrm{g}$; (c) Effect of hydrolysis E/S determined at the hydrolysis temperature of $60{ }^{\circ} \mathrm{C}$ and the hydrolysis time of $3 \mathrm{~h}$. The graphs show data from triplicate experiments (mean $\pm \mathrm{SD}$ ).

\subsection{The Collagen Hydrolysate Prepared with Aa2_1884 Is Rich in Collagen Oligopeptides}

To evaluate the quality of the prepared hydrolysate, we analyzed the contents of amino acids and peptides, amino acid composition, and molecular weight distribution of peptides in the hydrolysate. According to the ninhydrin method, there were $2.2 \pm 0.1 \%$ free amino acids and $97.8 \pm 0.1 \%$ peptides in the hydrolysate. Analysis of the composition of free amino acids in the hydrolysate by automatic amino acid analyzer also showed that there was only a small amount of free amino acids in the hydrolysate (Table 3). Thus, the hydrolysate is rich in peptides. In the hydrolysate, glycine is the most abundant $(17.2 \%)$, followed by proline $(10.1 \%)$. In addition, there were $1.0 \%$ hydroxylysine and $8.2 \%$ hydroxyproline in the peptides in the hydrolysate (Table 3). As hydroxylysine and hydroxyproline are two unique amino acids in collagen, our results indicated that the hydrolysate is rich in collagen peptides. The molecular weight distribution of peptides in the hydrolysate was analyzed by high performance liquid chromatography (HPLC) (Figure 7). The results showed that peptides with a molecular weight lower than $3000 \mathrm{Da}, 1000 \mathrm{Da}$, and $500 \mathrm{Da}$ accounted for approximately $71.6 \pm 0.2 \%, 55.1 \pm 0.2 \%$, and $39.5 \pm 0.2 \%$, respectively (Table 4 ), indicating that the hydrolysate is rich in collagen oligopeptides.

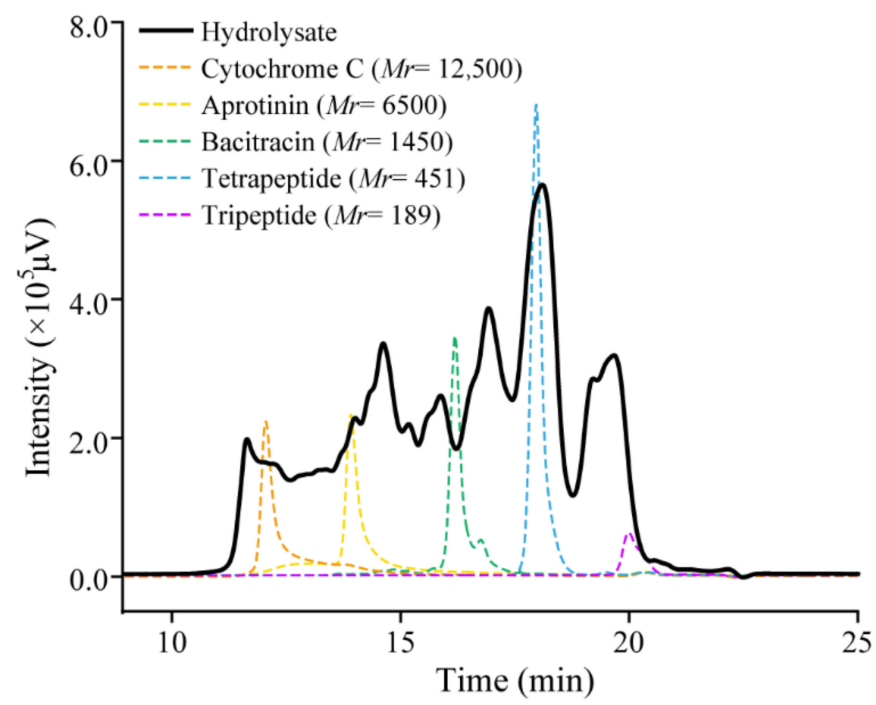

Figure 7. Size exclusion chromatography analysis of the molecular weight distribution of peptides in the hydrolysate. The hydrolysate dissolved in deionized water was analyzed by HPLC with a TSK gel G2000 SWXL column. 
Table 3. Composition and content of free and total amino acids in the hydrolysate ${ }^{\text {a }}$.

\begin{tabular}{ccc}
\hline Amino Acid & $\begin{array}{c}\text { Total Amino Acids } \\
(\mathbf{g} / \mathbf{1 0 0} \mathbf{~})\end{array}$ & $\begin{array}{c}\text { Free Amino Acids } \\
\text { (g/100 } \mathbf{~})\end{array}$ \\
\hline Ala & $6.87 \pm 0.05$ & $0.07 \pm 0.02$ \\
Arg & $7.16 \pm 0.06$ & \\
Asp & $3.39 \pm 0.03$ & $0.10 \pm 0.02$ \\
Cit & $0.07 \pm 0.03$ & \\
Cys & $0.56 \pm 0.04$ & $0.12 \pm 0.01$ \\
Glu & $4.04 \pm 0.03$ & \\
Gly & $17.21 \pm 0.12$ & $0.02 \pm 0.01$ \\
His & $0.67 \pm 0.02$ & \\
Ile & $1.54 \pm 0.04$ & $0.07 \pm 0.01$ \\
Leu & $2.73 \pm 0.06$ & $0.04 \pm 0.01$ \\
Lys & $3.23 \pm 0.05$ & \\
Met & $0.75 \pm 0.06$ & $0.10 \pm 0.01$ \\
Orn & $0.17 \pm 0.01$ & \\
Phe & $1.83 \pm 0.11$ & \\
Pro & $10.10 \pm 0.08$ & \\
Ser & $3.03 \pm 0.03$ & $0.15 \pm 0.04$ \\
Thr & $2.47 \pm 0.03$ & \\
Trp b & - & \\
Tyr & $0.79 \pm 0.10$ & $0.09 \pm 0.07$ \\
Val & $2.10 \pm 0.02$ & $0.14 \pm 0.01$ \\
Hylys & $1.04 \pm 0.05$ & $0.19 \pm 0.05$ \\
Hypro & $8.18 \pm 0.11$ &
\end{tabular}

${ }^{a}$ Composition and content of free and total amino acids in the hydrolysate were analyzed by using an amino acid analyzer. The data represent the mean \pm SD of three experimental repeats; ${ }^{b}$ Trp was not detectable because it was destroyed in the process of acid hydrolysis.

Table 4. Molecular weight distribution of peptides in the hydrolysate ${ }^{\text {a }}$.

\begin{tabular}{cc}
\hline $\begin{array}{c}\text { Molecular-Weight Range } \\
\text { (Da) }\end{array}$ & $\begin{array}{c}\text { Hydrolysate } \\
\text { (\%) }\end{array}$ \\
\hline$>10,000$ & $9.68 \pm 0.13$ \\
$5000-10,000$ & $6.25 \pm 0.02$ \\
$3000-5000$ & $12.46 \pm 0.11$ \\
$1000-3000$ & $16.49 \pm 0.09$ \\
$500-1000$ & $15.60 \pm 0.07$ \\
$<500$ & $39.50 \pm 0.20$
\end{tabular}

a The content of each range of peptides in the hydrolysate were calculated based on the percentage of the area of corresponding molecular weight range in the total chromatograph area of the hydrolysate in the HPLC chromatogram.

\subsection{Antioxidant Activity of Bovine Bone Collagen Hydrolysate}

The antioxidant activity of the hydrolysate was further evaluated by measuring its free radical scavenging activity towards 1,1-diphenyl-2-picryl-hydrazyl radical (DPPH•) with hyaluronic acid (HA) as a control. The scavenging ratio of the hydrolysate to DPPH• increased with the hydrolysate concentration, which reached $32.8 \pm 1.1 \%$ at the concentration of $10 \mathrm{mg} / \mathrm{mL}$ (Figure 8). In addition, as shown in Figure 8, the DPPH• scavenging ratio of the hydrolysate was obviously higher than that of HA, especially at high concentrations. A comparison of the DPPH• scavenging ratio of the hydrolysate with those of some reported collagen hydrolysates are shown in Table 5. The differences in the DPPH• scavenging ratios among the hydrolysates are likely attributed to the differences in the collagen sources, the preparation methods, and the enzymes used. 


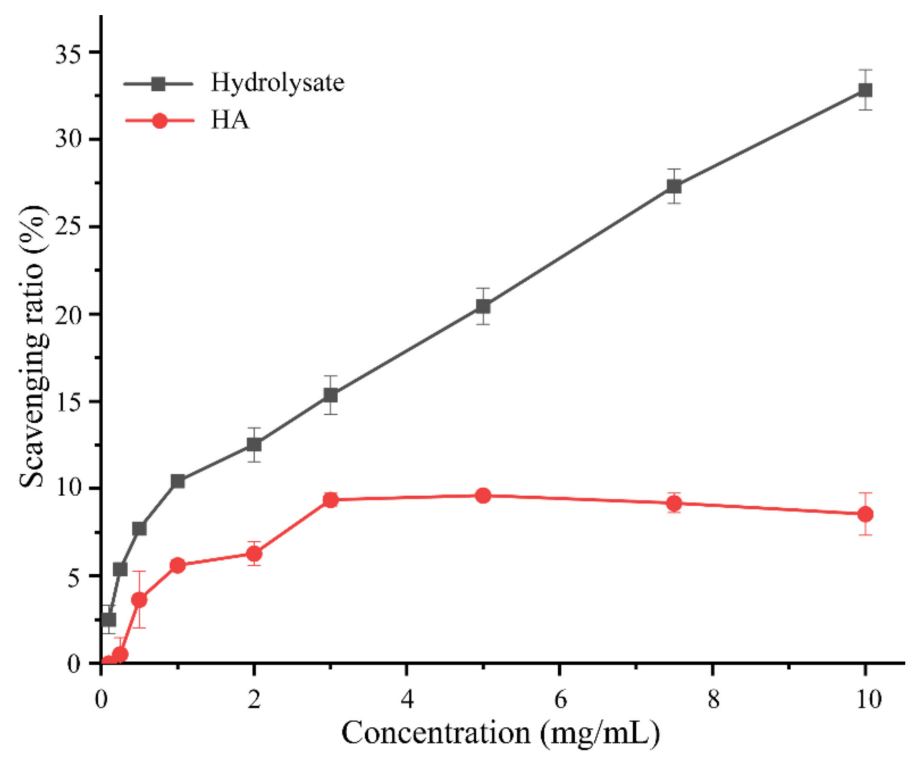

Figure 8. Antioxidant activity towards DPPH• of the hydrolysate and hyaluronic acid (HA).

Table 5. Antioxidant activity towards DPPH• of collagen hydrolysates prepared from different collagen sources by different methods.

\begin{tabular}{|c|c|c|c|c|c|}
\hline Antioxidant Activity & $\begin{array}{l}\text { Hydrolysate Concentration } \\
(\mathrm{mg} / \mathrm{mL})\end{array}$ & Enzyme & Method & Collagen Source & Reference \\
\hline $32.8 \%{ }^{\mathrm{a}}$ & 10 & Aa2_1884 (S8) & Enzymolysis & Bovine bone & This study \\
\hline $40.7 \%{ }^{\mathrm{a}}$ & 30 & A69 (M4) & Enzymolysis & Bovine bone & [43] \\
\hline $341.91 \%$ a & 10 & MCP-01 (S8) & Enzymolysis & Fish skin & [7] \\
\hline $50 \%^{a}$ & 8.38 & & $\mathrm{SWH}^{\mathrm{b}}$ & Fish bone & [44] \\
\hline $50 \%$ a & 7.58 & & SWH & Fish skin & [44] \\
\hline $50 \%{ }^{a}$ & 5.81 & Pepsin & Enzymolysis & Fish skin & [45] \\
\hline $50 \%{ }^{a}$ & 1.57 & Pepsin & $\begin{array}{l}\text { Enzymolysis and } \\
\text { fraction isolation }\end{array}$ & Fish skin & [46] \\
\hline
\end{tabular}

${ }^{a} \mathrm{DPPH} \bullet$ scavenging ratio, ${ }^{\mathrm{b}} \mathrm{SWH}$, subcritical water hydrolysis.

As oligopeptides from various proteins have been demonstrated as beneficial compounds for skin protection or against diseases such as hypertension, hypercholesterolemia, and atherosclerosis, oligopeptides have been widely prepared from a variety of proteins, including proteins from various plant fruits and seeds, and proteins from skins and meats of various marine and terrestrial animals $[4,47,48]$. Protein hydrolysates containing oligopeptides have been prepared with both commercial and non-commercial proteases. For example, a loach protein hydrolysate prepared with papain contained approximately $30 \%$ oligopeptides with a molecular weight lower than $500 \mathrm{Da}$, and exhibited good hydroxyl radical scavenging and antioxidant activities [49]. A salmon skin hydrolysate prepared with alcalase and papain contained approximately $90 \%$ oligopeptides with a molecular weight lower than $1000 \mathrm{Da}$, and showed the ACE inhibitory effect from different fractions collected by reversed-phase HPLC [19]. A 1301 Da peptide from the cod fish skin hydrolysate prepared with pepsin, trypsin, and $\alpha$-chymotrypsin exhibited potent $\mathrm{ACE}$ inhibitory and antioxidant activities [20]. A shrimp hydrolysate prepared with the crude enzyme from Bacillus sp. SM98011 contained approximately 41\% oligopeptides with molecular mass lower than $3000 \mathrm{Da}$, and exhibited good hydroxyl radical scavenger and antioxidant activities [50]. A codfish skin hydrolysate prepared with the collagenolytic protease MCP-01 from Pseudoalteromonas sp. SM9913 contained 60\% oligopeptides with a molecular weight lower than $1000 \mathrm{Da}$, and exhibited good hydroxyl radical scavenging activity and promoted an effect on cell viability of human dermal fibroblasts [7]. A bovine bone collagen hydrolysate prepared with the thermolysin-like protease A69 from Anoxybacillus caldiproteolyticus 1A02591 contained 21.1\% oligopeptides with a molecular 
weight lower than $1000 \mathrm{Da}$, and exhibited good moisture-retention ability and antioxidant activity [43]. The hydrolysate prepared from Bigeye tuna skin collagen contained peptides with molecular weights of 300-425 Da and had DPPH• scavenging activity [51]. It has been demonstrated that di-/tripeptides can be absorbed in their intact forms in human intestine without further hydrolysis [5]. Thus, protein hydrolysates containing more oligo-peptides with a molecular weight of $<1000$ Da or even $<500$ Da are preferred in cosmetics, functional food, and nutraceuticals [52].

Collagen used in collagen oligopeptides preparation have been extracted from the bones and skins of various animals, such as fish skins and bones [7,44,53], and goat skin [54]. Bovine bone is a by-product of beef processing industry and its annual production is huge due to the large number of global slaughtered cattle. Bovine bone is rich in collagen and therefore, is a cheap and good source for collagen preparation. However, bovine bone collagen has rarely been used in collagen oligopeptide preparation to our knowledge. In this study, we used Aa2_1884 to prepare collagen oligopeptides from bovine bone collagen. Aa2_1884 showed a high hydrolysis efficiency (95\%) on bovine bone collagen and the resultant hydrolysate contained a high proportion of collagen oligopeptides, $55.1 \%$ peptides with a molecular weight lower than $1000 \mathrm{Da}$, and 39.5\% peptides with a molecular weight lower than 500 Da. These data suggest that Aa2_1884 has a promising potential in preparing collagen oligopeptides from bovine bone collagen, which may provide a feasible way for the high-value utilization of bovine bone collagen.

\section{Materials and Methods}

\subsection{Materials}

Bovine tendon collagen was purchased from Worthington (Lakewood, NJ, USA), and bovine bone collagen from Kinry Biotech Co., Ltd. (Jinan, China). Casein (from bovine milk), gelatin (from cold water fish skin), elastin-orcein, EGTA, $o-P$, aprotinin, and cytochrome C were purchased from Sigma (St. Louis, MO, USA). Alcalase was purchased from Vazyme Biotech Co., Ltd. (Nanjing, China). PMSF was purchased from BBI (Shanghai, China). EDTA was purchased from HUSHI (Shanghai, China). Bacitracin was purchased from Aladdin (Shanghai, China). Tripeptide GGG and tetrapeptide GGYR were synthesized by Qiangyao Biotechnology Co., Ltd. (Shanghai, China). DPPH• was purchased from Tokyo Chemical Industry (Tokyo, Japan). HA was purchased from Shandong Freda Bioeng Co., Ltd. (Jinan, China). Other chemicals were of analytical grade and commercially available.

\subsection{Sequence Analysis}

The domains of Aa2_1884 (WP_199608745) from Flocculibacter collagenilyticus SM1988 (CP05988) and of the other proteases shown in Figure 1 were predicted by InterPro (https: //www.ebi.ac.uk/interpro/; 6 December 2021) [55]. The signal peptide of Aa2_1884 was predicted by the SignalP 5.0 server (https: / / services.healthtech.dtu.dk/service.php? SignalP-5.0; 6 December 2021) [56]. For sequence alignment, previously reported MCP-01 (ABD14413) from Pseudoalteromonas sp. SM9913, the collagenolytic protease (BAF30978) from Geobacillus sp. MO-1, myroicolsin (AEC33275) from Myroides profundi D25, and P57 (KT923662) from Photobacterium sp. A5-7 were selected to align with Aa2_1884 by ClustalW with bootstrap of 1000 [57]. The sequence alignment was displayed using ESPript 3.0 [58]. The conserved sites were predicted by MEME (https://meme-suite.org/meme /; 6 December 2021) [59]. The phylogenetic tree was constructed via MEGA X [60].

\subsection{Protein Expression and Purification}

The genome DNA of strain SM1988 was extracted with bacterial genomic DNA isolation kit (BioTeke, Beijing, China) according to the manufacturer's instructions. The gene sequence of Aa2_1884 was amplified by PCR using the genome DNA of strain SM1988 with primers 1884-F (5'-AAGAAGGAGATATACATATGATGAAAATAGAACATAGT-3') and 1884-R (5'-TGGTGGTGGTGGTGCTCGAGTTTATTGTCACACGTGGTT-3'). The primers were synthesized by Tsingke Biotechnology Co., Ltd. (Qingdao, China). The PCR product 
was then cloned into vector pET-22b (+) (Vazyme) with a C-terminal His tag. The constructed plasmid carrying the gene sequence of Aa2_1884 was verified by sequencing and then transformed into Fe2 BL21 (DE3). Recombinant E. coli cells were cultured in Lysogeny broth (LB) medium with $100 \mu \mathrm{g} / \mathrm{mL}$ ampicillin at $37^{\circ} \mathrm{C}, 180 \mathrm{rpm}$ to an $\mathrm{OD}_{600}$ of $0.8-1.0$. Then, $0.2 \mathrm{mM}$ isopropyl $\beta$-D-1-thiogalactopyranoside (IPTG) was added, and the cells were further incubated at $15^{\circ} \mathrm{C}, 120 \mathrm{rpm}$ for 5 days [26]. After incubation, cells were lysed by a high-pressure cracker and centrifuged at $4656 \times g, 4{ }^{\circ} \mathrm{C}$ for $1 \mathrm{~h}$, and the supernatant was collected. The recombinant Aa2_1884 protein was extracted from the supernatant by an His binding Ni chelating column, and then purified on a Sephadex G200 gel filtration column (GE, Boston, MA, USA) using fast protein liquid chromatography (FPLC) on AKTA purifier (GE, Boston, MA, USA) [61]. The purified Aa2_1884 was analyzed by $12.5 \%$ SDS-PAGE. Protein concentration was determined by a BCA protein assay kit (Thermo, Waltham, MA, USA) with bovine serum albumin (BSA) as the standard according to the manufacturer's instructions.

\subsection{Enzyme Assay}

The activities of Aa2_1884 toward bovine bone collagen, bovine tendon collagen, and gelatin at $60{ }^{\circ} \mathrm{C}$ were measured by the method provided by Worthington Biochemical Co. (Lakewood, NJ, USA) [26]. For collagen, a mixture of $5 \mathrm{mg}$ substrate and $1 \mathrm{~mL}$ enzyme solution was incubated at $60{ }^{\circ} \mathrm{C}$ in Tris- $\mathrm{HCl}$ buffer for $0.5 \mathrm{~h}$ with continuous stirring. For gelatin, $100 \mu \mathrm{L}$ enzyme solution was incubated with $100 \mu \mathrm{L}$ of $2 \%(w / v)$ gelatin at $60^{\circ} \mathrm{C}$ for $10 \mathrm{~min}$. The reaction was stopped by the addition of $10 \mu \mathrm{L}$ of $1.25 \mathrm{M}$ trichloroacetic acid. The released amino acids were quantified using the colorimetric ninhydrin method [62] with L-leucine as the standard. One unit of enzyme activity was defined as the amount of enzyme that released $1 \mathrm{nmol}$ of L-leucine per hour from collagen or gelatin [26]. The caseinolytic activity was determined at $60^{\circ} \mathrm{C}$ using the method described by He et al. [63]. A reaction mixture containing $100 \mu \mathrm{L}$ enzyme solution and $100 \mu \mathrm{L}$ of $2 \%(w / v)$ casein was incubated at $60{ }^{\circ} \mathrm{C}$ for $10 \mathrm{~min}$, and then the reaction was terminated by $200 \mu \mathrm{L}$ trichloroacetic acid $(0.4 \mathrm{M})$. The mixture was centrifuged at $17,935 \times \mathrm{g}$ for $10 \mathrm{~min}$, and $100 \mu \mathrm{L}$ of the supernatant was incubated with $500 \mu \mathrm{L}$ of sodium carbonate solution $(0.4 \mathrm{M})$ and $100 \mu \mathrm{L}$ of the Folin-phenol reagent at $40^{\circ} \mathrm{C}$ for $20 \mathrm{~min}$. After the reaction, the $\mathrm{OD}_{660}$ of the mixture was measured. One unit of enzyme activity was defined as the amount of enzyme that liberated $1 \mathrm{mg}$ tyrosine per minute [63]. The elastolytic activity at $60{ }^{\circ} \mathrm{C}$ was determined using the method described by Chen [64]. A mixture of $250 \mu \mathrm{L}$ enzyme solution and $5 \mathrm{mg}$ elastin-orcein was incubated at $60^{\circ} \mathrm{C}$ for $1 \mathrm{~h}$. After the reaction, the residual elastin-orcein was removed by centrifugation. The $\mathrm{OD}_{590}$ of the supernatant was recorded. One unit of enzyme activity was defined as the amount of enzyme that caused an increase of 0.01 in $\mathrm{OD}_{590}$ per minute [64].

\subsection{Enzyme Characterization}

The optimal temperature was determined by measuring the activity of Aa2_1884 toward bovine bone collagen in Tris- $\mathrm{HCl}$ buffer $(50 \mathrm{mM}, \mathrm{pH} 9.0)$ at $40,50,60,70$, and $80{ }^{\circ} \mathrm{C}$. The optimal $\mathrm{pH}$ was determined by measuring the activity of Aa2_1884 toward bovine bone collagen at $60^{\circ} \mathrm{C}$ in $40 \mathrm{mM}$ Britton-Robinson buffers from $\mathrm{pH} 7.0$ to $\mathrm{pH}$ 11.0. The effect of $\mathrm{NaCl}$ concentration on the activity of Aa2_1884 was determined by measuring the activity of Aa2_1884 toward bovine bone collagen in Tris- $\mathrm{HCl}$ buffer $(50 \mathrm{mM}, \mathrm{pH} 9.0)$ containing $\mathrm{NaCl}$ of different concentrations $(0-4 \mathrm{M})$ at $60^{\circ} \mathrm{C}$. To evaluate the effect of metal ions $\left(\mathrm{Li}^{+}, \mathrm{K}^{+}, \mathrm{Ca}^{2+}, \mathrm{Mg}^{2+}, \mathrm{Cu}^{2+}, \mathrm{Ni}^{2+}, \mathrm{Mn}^{2+}, \mathrm{Ba}^{2+}, \mathrm{Fe}^{2+}, \mathrm{Zn}^{2+}, \mathrm{Co}^{2+}, \mathrm{Sn}^{2+}, \mathrm{Sr}^{2+}\right)$ on the enzymatic activity, Aa2_1884 was incubated in Tris- $\mathrm{HCl}$ buffer $(50 \mathrm{mM}, \mathrm{pH}$ 9.0) containing each metal ion ( $2 \mathrm{mM}$ or $4 \mathrm{mM}$ ) at $4{ }^{\circ} \mathrm{C}$ for $1 \mathrm{~h}$, and the enzymatic activity toward bovine bone collagen was then measured at $60^{\circ} \mathrm{C}$. For the inhibitory experiment, Aa2_1884 and alcalase were incubated at $4{ }^{\circ} \mathrm{C}$ for $1 \mathrm{~h}$ with $2 \mathrm{mM}$ of an inhibitor, PMSF, EDTA, EGTA, or $o$-P. After incubation, the residue activity toward bovine bone collagen was measured at $60{ }^{\circ} \mathrm{C}$ and $\mathrm{pH} 9.0$. 


\subsection{Optimization of the Enzymatic Hydrolysis Parameters}

Three parameters, hydrolysis temperature, hydrolysis time, and E/S, which influence the efficiency of the enzymatic hydrolysis, were optimized via single-factor experiments, in which enzymatic hydrolysis of $10 \mathrm{mg}$ bovine bone collagen in $1 \mathrm{~mL} 50 \mathrm{mM}$ Tris- $\mathrm{HCl}$ (pH 9.0) was performed at $180 \mathrm{rpm}$ in a shaking bath. Each parameter was determined under the optimum conditions of the other two parameters. To determine the hydrolysis temperature, the enzymatic hydrolysis was performed at different hydrolysis temperature $\left(40,45,50,55,60,65,70^{\circ} \mathrm{C}\right)$. To determine the hydrolysis time, the enzymatic hydrolysis was performed for different time $(0.5,1,1.5,2,2.5,3,3.5,4,4.5,5 \mathrm{~h})$. To determine the $\mathrm{E} / \mathrm{S}$, the enzymatic hydrolysis was performed with different $\mathrm{E} / \mathrm{S}(0,4,8,40,80,160,400,600$, $800 \mathrm{U} / \mathrm{g}$ collagen). After the hydrolysis, the reaction system was heated at $90^{\circ} \mathrm{C}$ for $15 \mathrm{~min}$ to terminate the reaction, and then centrifuged at $4{ }^{\circ} \mathrm{C}$ for $20 \mathrm{~min}$. The precipitate was freeze-dried and weighted, which was taken as the residual amount of collagen.

\subsection{Preparation and Evaluation of Collagen Hydrolysate}

To prepare peptides from bovine bone collagen, $10 \mathrm{mg}$ bovine bone collagen was hydrolyzed under the determined parameters (at $60^{\circ} \mathrm{C}$ for $3 \mathrm{~h}$ with an $\mathrm{E} / \mathrm{S}$ ratio of $400 \mathrm{U} / \mathrm{g}$ ). After hydrolysis, the reaction system was heated at $90{ }^{\circ} \mathrm{C}$ for $15 \mathrm{~min}$ and then centrifuged at $4{ }^{\circ} \mathrm{C}$ for $20 \mathrm{~min}$. The supernatant was collected, freeze-dried, and weighted, which was the prepared hydrolysate.

Ten milligrams of the hydrolysate were dissolved in $1 \mathrm{~mL}$ deionized water. With L-leucine as the standard, the content of free amino acids in the hydrolysate solution was determined by the ninhydrin method [62]. The content of peptides in the hydrolysate was calculated by subtracting the content of free amino acids from that of the hydrolysate in the solution [43]. The compositions of free and total amino acids of the hydrolysate were analyzed by using an amino acid analyzer HITACHI 835 (Tokyo, Japan). The molecular mass distribution of peptides in the hydrolysates were analyzed by the method described by [7]. Briefly, the hydrolysate was dissolved with deionized water, and then analyzed by HPLC (LC-20AD, SHIMADZU, Tokyo, Japan) equipped with a TSK gel G2000 SWXL column (300 $\times 7.8 \mathrm{~mm}$; range, $<150,000 \mathrm{Da}$; void volume, $5.7 \mathrm{~mL}$; Tosoh, Japan) that was eluted with the buffer containing $45 \%$ acetonitrile and $1 \%$ trifluoroacetic acid in deionized water at a flow rate of $0.5 \mathrm{~mL} / \mathrm{min}$ HPLC under $220 \mathrm{~nm}$ monitoring. The calibration standards for molecular mass were tripeptide Gly-Gly-Gly (GGG, $M r$ 189), tetrapeptide Gly-Gly-Tyr-Arg (GGYR, Mr 451), bacitracin (Mr 1422), aprotinin (Mr 6511), and cytochrome $\mathrm{C}(\mathrm{Mr}$ 12400). Based on the calibration standards, the chromatogram of the hydrolysate was separated into several fractions ( $<500 \mathrm{Da}, 500-1000 \mathrm{Da}, 1000-3000 \mathrm{Da}, 3000-5000 \mathrm{Da}$, $5000-10,000 \mathrm{Da}$, and $>10,000 \mathrm{Da}$ ), and the content of each fraction was determined by its relative peak area.

\subsection{Analysis of the Antioxidant Activity of the Collagen Hydrolysate}

The antioxidant activity of the prepared hydrolysate was analyzed by measuring its free radical scavenging activity towards 1,1-diphenyl-2-picryl-hydrazyl radical (DPPH•) according to the method described by Sun [65]. HA was used as a positive control due to its widespread application in scavenging free radical. To determine the DPPH• scavenging activity, $1 \mathrm{~mL}$ hydrolysate samples in incremental concentrations $(0.1,0.25,0.5,1,2,3,5$, $7.5,10 \mathrm{mg} / \mathrm{mL}$ ) were reacted with $2 \mathrm{~mL}$ of $100 \mu \mathrm{M}$ DPPH $\bullet$ (dissolved in ethanol solution) for $40 \mathrm{~min}$ at room temperature $\left(25^{\circ} \mathrm{C}\right)$ in dark, and then the absorbance of the reaction solution was detected at $525 \mathrm{~nm}$. DPPH solution was replaced with ethanol solution to obtain the result of background of sample, and the hydrolysate sample was replaced with water to obtain the result of blank control.

The free radical scavenging activity $(D)$ was calculated as follows:

$$
D(\%)=\left[1-\left(A_{i}-A_{j}\right) / A_{0}\right] * 100
$$


where $A_{i}$ was the absorbance of the sample, $A_{j}$ was the background absorbance of the sample, and $A_{0}$ was the absorbance of the blank control.

\section{Conclusions}

As only a few peptidases of the S8 family so far have been applied in the preparation of bioactive oligopeptides, there is still a need to develop more S8 serine peptidases with potentials in bioactive oligopeptide preparation. In this study, the peptidase Aa2_1884 from marine bacterium Flocculibacter collagenilyticus $\mathrm{SM} 1988^{\mathrm{T}}$ was demonstrated to be a novel multimodular gelatinase of the S8 family, which has high activity towards gelatin and denatured collagens. Moreover, under the optimized enzymolysis conditions, Aa2_1884 has a high hydrolysis efficiency (95\%) on bovine bone collagen. The prepared hydrolysate is rich in collagen oligopeptides and has antioxidant activity. The results in this study suggest that Aa2_1884 has a promising potential application in preparing collagen oligopeptides from bovine bone collagen. The collagen hydrolysate prepared with Aa2_1884 may have good bioactivities due to its high oligopeptide content as well as good antioxidant activity, which awaits further investigation.

Author Contributions: Conceptualization, X.-L.C. and Y.-Z.Z.; investigation, J.L. and J.-M.D.; methodology, J.L., J.-H.C., M.-L.S., J.-P.W. and X.Z.; software, Z.-J.T.; project administration, X.-L.C. and X.-Y.Z.; resources, X.-L.C. and X.-Y.Z.; supervision, X.-M.T. and X.-Y.Z.; writing-original draft preparation, J.L. and Z.-J.T.; writing—review and editing, X.-L.C. and X.-Y.Z. All authors have read and agreed to the published version of the manuscript.

Funding: This work was funded by the National Science Foundation of China (grant numbers U2006205, U1706207, 31670038 and 31971535, awarded to X.-L.C., Y.-Z.Z., X.-L.C. and Y.-Z.Z., respectively), the National Key R\&D Program of China (2018YFC0310704 awarded to X.-L.C.), the Major Scientific and Technological Innovation Project (MSTIP) of Shandong Province (2019JZZY010817 awarded to Y.-Z.Z.), Taishan Scholars Program of Shandong Province (tspd20181203, awarded to Y.-Z.Z.), and Scientific Research Think Tank of Biological Manufacturing Industry in Qingdao (QDSWZK202002 awarded to Y.-Z.Z.).

Data Availability Statement: The amino acid sequence of Aa2_1884 has been submitted to NCBI database under the accession number WP_199608745, It can be found here: https:/ /www.ncbi.nlm. nih.gov/protein/WP_199608745 (accessed on 6 December 2021).

Acknowledgments: The authors sincerely appreciate Jiaojiao Tian (Ocean University of China) for her assistance in the amino acid analyses. We also thank Jingyao Qu, Jing Zhu, and Zhifeng Li from State Key Laboratory of Microbial Technology, Shandong University, China for their help and guidance in LC-MS.

Conflicts of Interest: The authors declare no conflict of interest.

\section{References}

1. Zamyatnin, A.A. Structural-functional diversity of the natural oligopeptides. Prog. Biophys. Mol. Biol. 2018, 133, 1-8. [CrossRef]

2. Suarez-Jimenez, G.M.; Burgos-Hernandez, A.; Ezquerra-Brauer, J.M. Bioactive peptides and depsipeptides with anticancer potential: Sources from marine animals. Mar. Drugs 2012, 10, 963-986. [CrossRef] [PubMed]

3. Nasri, R.; Nasri, M. Marine-derived bioactive peptides as new anticoagulant agents: A review. Curr. Protein Pept. Sci. 2013, 14, 199-204. [CrossRef]

4. Bhat, Z.F.; Kumar, S.; Bhat, H.F. Bioactive peptides of animal origin: A review. J. Food Sci. Technol. 2015, 52, 5377-5392. [CrossRef]

5. Shen, W.; Matsui, T. Current knowledge of intestinal absorption of bioactive peptides. Food Funct. 2017, 8, 4306-4314. [CrossRef] [PubMed]

6. Ngo-Son, A.; Katekaew, S. Purification and characterization of angiotensin converting enzyme-inhibitory derived from crocodile blood hydrolysates. Food Sci. Technol. 2019, 39, 818-823. [CrossRef]

7. Chen, X.L.; Peng, M.; Li, J.; Tang, B.L.; Shao, X.; Zhao, F.; Liu, C.; Zhang, X.Y.; Li, P.Y.; Shi, M.; et al. Preparation and functional evaluation of collagen oligopeptide-rich hydrolysate from fish skin with the serine collagenolytic protease from Pseudoalteromonas sp. SM9913. Sci. Rep. 2017, 7, 15716. [CrossRef] [PubMed]

8. Chalamaiah, M.; Yu, W.; Wu, J. Immunomodulatory and anticancer protein hydrolysates (peptides) from food proteins: A review. Food Chem. 2018, 245, 205-222. [CrossRef] 
9. Salampessy, J.; Phillips, M.; Seneweera, S.; Kailasapathy, K. Release of antimicrobial peptides through bromelain hydrolysis of leatherjacket (Meuchenia sp.) insoluble proteins. Food Chem. 2010, 120, 556-560. [CrossRef]

10. Kim, D.U.; Chung, H.C.; Choi, J.; Sakai, Y.; Lee, B.Y. Oral Intake of Low-Molecular-Weight Collagen Peptide Improves Hydration, Elasticity, and Wrinkling in Human Skin: A Randomized, Double-Blind, Placebo-Controlled Study. Nutrients 2018, $10,826$. [CrossRef]

11. Liu, J.; Wang, J.; Guo, Y. Effect of Collagen Peptide, Alone and in Combination with Calcium Citrate, on Bone Loss in TailSuspended Rats. Molecules 2020, 25, 782. [CrossRef] [PubMed]

12. Zdzieblik, D.; Oesser, S.; Baumstark, M.W.; Gollhofer, A.; König, D. Collagen peptide supplementation in combination with resistance training improves body composition and increases muscle strength in elderly sarcopenic men: A randomised controlled trial. Br. J. Nutr. 2015, 114, 1237-1245. [CrossRef] [PubMed]

13. Qiao, L.; Li, B.; Chen, Y.; Li, L.; Chen, X.; Wang, L.; Lu, F.; Luo, G.; Li, G.; Zhang, Y. Discovery of Anti-Hypertensive Oligopeptides from Adlay Based on In Silico Proteolysis and Virtual Screening. Int. J. Mol. Sci. 2016, 17, 2099. [CrossRef] [PubMed]

14. Lee, E.J.; Hur, J.; Ham, S.A.; Jo, Y.; Lee, S.; Choi, M.J.; Seo, H.G. Fish collagen peptide inhibits the adipogenic differentiation of preadipocytes and ameliorates obesity in high fat diet-fed mice. Int. J. Biol. Macromol. 2017, 104, 281-286. [CrossRef]

15. Zdzieblik, D.; Oesser, S.; Gollhofer, A.; König, D. Improvement of activity-related knee joint discomfort following supplementation of specific collagen peptides. Appl. Physiol. Nutr. Metab. 2017, 42, 588-595. [CrossRef] [PubMed]

16. Bello, A.E.; Oesser, S. Collagen hydrolysate for the treatment of osteoarthritis and other joint disorders: A review of the literature. Curr. Med. Res. Opin. 2006, 22, 2221-2232. [CrossRef]

17. Kang, M.C.; Yumnam, S.; Kim, S.Y. Oral Intake of Collagen Peptide Attenuates Ultraviolet B Irradiation-Induced Skin Dehydration In Vivo by Regulating Hyaluronic Acid Synthesis. Int. J. Mol. Sci. 2018, 19, 3551. [CrossRef]

18. Korhonen, H.; Pihlanto, A. Food-derived bioactive peptides-Opportunities for designing future foods. Curr. Pharm. Des. 2003, 9 , 1297-1308. [CrossRef]

19. Gu, R.-Z.; Li, C.-Y.; Liu, W.-Y.; Yi, W.-X.; Cai, M.-Y. Angiotensin I-converting enzyme inhibitory activity of low-molecular-weight peptides from Atlantic salmon (Salmo salar L.) skin. Food Res. Int. 2011, 44, 1536-1540. [CrossRef]

20. Himaya, S.W.A.; Ngo, D.-H.; Ryu, B.; Kim, S.-K. An active peptide purified from gastrointestinal enzyme hydrolysate of Pacific cod skin gelatin attenuates angiotensin-1 converting enzyme (ACE) activity and cellular oxidative stress. Food Chem. 2012, 132, 1872-1882. [CrossRef]

21. Li, Z.-R.; Wang, B.; Chi, C.-f.; Zhang, Q.-H.; Gong, Y.-d.; Tang, J.-J.; Luo, H.-y.; Ding, G.-f. Isolation and characterization of acid soluble collagens and pepsin soluble collagens from the skin and bone of Spanish mackerel (Scomberomorous niphonius). Food Hydrocoll. 2013, 31, 103-113. [CrossRef]

22. Adekoya, O.A.; Sylte, I. The thermolysin family (M4) of enzymes: Therapeutic and biotechnological potential. Chem. Biol. Drug Des. 2009, 73, 7-16. [CrossRef]

23. Rawlings, N. Introduction: Serine Peptidases and Their Clans. In Handbook of Proteolytic Enzymes, 2nd ed.; Academic Press: San Diego, CA, USA, 2004

24. Okamoto, M.; Yonejima, Y.; Tsujimoto, Y.; Suzuki, Y.; Watanabe, K. A thermostable collagenolytic protease with a very large molecular mass produced by thermophilic Bacillus sp. strain MO-1. Appl. Microbiol. Biotechnol. 2001, 57, 103-108. [CrossRef]

25. Chen, X.L.; Xie, B.B.; Lu, J.T.; He, H.L.; Zhang, Y. A novel type of subtilase from the psychrotolerant bacterium Pseudoalteromonas sp. SM9913: Catalytic and structural properties of deseasin MCP-01. Microbiology 2007, 153, 2116-2125. [CrossRef] [PubMed]

26. Ran, L.Y.; Su, H.N.; Zhou, M.Y.; Wang, L.; Chen, X.L.; Xie, B.B.; Song, X.Y.; Shi, M.; Qin, Q.L.; Pang, X.; et al. Characterization of a novel subtilisin-like protease myroicolsin from deep sea bacterium Myroides profundi D25 and molecular insight into its collagenolytic mechanism. J. Biol. Chem. 2014, 289, 6041-6053. [CrossRef] [PubMed]

27. Li, H.J.; Tang, B.L.; Shao, X.; Liu, B.X.; Zheng, X.Y.; Han, X.X.; Li, P.Y.; Zhang, X.Y.; Song, X.Y.; Chen, X.L. Characterization of a New S8 serine Protease from Marine Sedimentary Photobacterium sp. A5-7 and the Function of Its Protease-Associated Domain. Front. Microbiol. 2016, 7, 2016. [CrossRef] [PubMed]

28. Abdul-Hamid, A.; Bakar, J.; Bee, G.H. Nutritional quality of spray dried protein hydrolysate from Black Tilapia (Oreochromis mossambicus). Food Chem. 2002, 78, 69-74. [CrossRef]

29. Li, J.; Cheng, J.H.; Teng, Z.J.; Sun, Z.Z.; He, X.Y.; Wang, P.; Shi, M.; Song, X.Y.; Chen, X.L.; Zhang, Y.Z.; et al. Taxonomic and Enzymatic Characterization of Flocculibacter collagenilyticus gen. nov., sp. nov., a Novel Gammaproteobacterium With High Collagenase Production. Front. Microbiol. 2021, 12, 621161. [CrossRef]

30. Li, Y.; Hu, Z.; Jordan, F.; Inouye, M. Functional Analysis of the Propeptide of Subtilisin E as an Intramolecular Chaperone for Protein Folding: Refolding And Inhibitory Abilities of Propeptide Mutants (*). J. Biol. Chem. 1995, 270, 25127-25132. [CrossRef]

31. Kojima, S.; Minagawa, T.; Miura, K. The propeptide of subtilisin BPN' as a temporary inhibitor and effect of an amino acid replacement on its inhibitory activity. FEBS Lett. 1997, 411, 128-132. [CrossRef]

32. Luo, X.; Hofmann, K. The protease-associated domain: A homology domain associated with multiple classes of proteases. Trends Biochem. Sci. 2001, 26, 147-148. [CrossRef]

33. Kagawa, T.F.; O'Connell, M.R.; Mouat, P.; Paoli, M.M.; O’Toole, P.W.; Cooney, J.C. Model for substrate interactions in C5a peptidase from Streptococcus pyogenes: A 1.9 A crystal structure of the active form of ScpA. J. Mol. Biol. 2009, 386, 754-772. [CrossRef] 
34. Morrissey, J.H. Chapter 641-Coagulation Factor VIIa. In Handbook of Proteolytic Enzymes, 3rd ed.; Rawlings, N.D., Salvesen, G., Eds.; Academic Press: Cambridge, MA, USA, 2013; pp. 2905-2908.

35. Page, M.J.; Craik, C.S. Chapter 669-Brachyurins. In Handbook of Proteolytic Enzymes, 3rd ed.; Rawlings, N.D., Salvesen, G., Eds.; Academic Press: Cambridge, MA, USA, 2013; pp. 3049-3052.

36. Fuller, R.S.; Brake, A.; Thorner, J. Yeast prohormone processing enzyme (KEX2 gene product) is a Ca ${ }^{2+}$-dependent serine protease. Proc. Natl. Acad. Sci. USA 1989, 86, 1434-1438. [CrossRef]

37. Zhou, A.; Martin, S.; Lipkind, G.; LaMendola, J.; Steiner, D.F. Regulatory roles of the P domain of the subtilisin-like prohormone convertases. J. Biol. Chem. 1998, 273, 11107-11114. [CrossRef] [PubMed]

38. Rawlings, N.D.; Barrett, A.J. Chapter 559-Introduction: Serine Peptidases and Their Clans. In Handbook of Proteolytic Enzymes, 3rd ed.; Rawlings, N.D., Salvesen, G., Eds.; Academic Press: Cambridge, MA, USA, 2013; pp. 2491-2523.

39. Graycar, T.P.; Bott, R.R.; Power, S.D.; Estell, D.A. Chapter 693-Subtilisins. In Handbook of Proteolytic Enzymes, 3rd ed.; Rawlings, N.D., Salvesen, G., Eds.; Academic Press: Cambridge, MA, USA, 2013; pp. 3148-3155.

40. Sacco, E.; Elena Regonesi, M.; Vanoni, M. Chapter 711-Archaean Serine Proteases. In Handbook of Proteolytic Enzymes, 3rd ed.; Rawlings, N.D., Salvesen, G., Eds.; Academic Press: Cambridge, MA, USA, 2013; pp. 3224-3233.

41. Uesugi, Y.; Arima, J.; Usuki, H.; Iwabuchi, M.; Hatanaka, T. Two bacterial collagenolytic serine proteases have different topological specificities. Biochim. Biophys. Acta 2008, 1784, 716-726. [CrossRef] [PubMed]

42. Tsuruoka, N.; Nakayama, T.; Ashida, M.; Hemmi, H.; Nakao, M.; Minakata, H.; Oyama, H.; Oda, K.; Nishino, T. Collagenolytic serine-carboxyl proteinase from Alicyclobacillus sendaiensis strain NTAP-1: Purification, characterization, gene cloning, and heterologous expression. Appl. Environ. Microbiol. 2003, 69, 162-169. [CrossRef] [PubMed]

43. Cheng, J.-H.; Zhang, X.-Y.; Wang, Z.; Zhang, X.; Liu, S.-C.; Song, X.-Y.; Zhang, Y.-Z.; Ding, J.-M.; Chen, X.-L.; Xu, F. Potential of Thermolysin-like Protease A69 in Preparation of Bovine Collagen Peptides with Moisture-Retention Ability and Antioxidative Activity. Mar. Drugs 2021, 19, 676. [CrossRef] [PubMed]

44. Asaduzzaman, A.K.M.; Getachew, A.T.; Cho, Y.-J.; Park, J.-S.; Haq, M.; Chun, B.-S. Characterization of pepsin-solubilised collagen recovered from mackerel (Scomber japonicus) bone and skin using subcritical water hydrolysis. Int. J. Biol. Macromol. 2020, 148, 1290-1297. [CrossRef]

45. Medina-Medrano, J.R.; Quiñones-Muñoz, T.A.; Arce-Ortíz, A.; Torruco-Uco, J.G.; Hernández-Martínez, R.; Lizardi-Jiménez, M.A.; Varela-Santos, E. Antioxidant Activity of Collagen Extracts Obtained from the Skin and Gills of Oreochromis sp. J. Med. Food 2019, 22, 722-728. [CrossRef]

46. Zhang, J.B.; Zhao, Y.Q.; Wang, Y.M.; Chi, C.F.; Wang, B. Eight Collagen Peptides from Hydrolysate Fraction of Spanish Mackerel Skins: Isolation, Identification, and In Vitro Antioxidant Activity Evaluation. Mar. Drugs 2019, 17, 224. [CrossRef]

47. Yu, C.; Xiong, Y.L.; Jie, C. Andoxidant and emulsifying properties of potato protein hydrolysate in soybean oil-in-water emulsions. Food Chem. 2010, 120, 101-108.

48. Jahanbani, R.; Ghaffari, S.M.; Salami, M.; Vahdati, K.; Sepehri, H.; Sarvestani, N.N.; Sheibani, N.; Moosavi-Movahedi, A.A. Antioxidant and Anticancer Activities of Walnut (Juglans regia L.) Protein Hydrolysates Using Different Proteases. Plant. Food Hum. Nutr. 2016, 71, 402-409. [CrossRef] [PubMed]

49. You, L.J. Effect of degree of hydrolysis on the antioxidant activity of loach (Misgurnus anguillicaudatus) protein hydrolysates. Innov. Food Sci. Emerg. 2009, 10, 235-240. [CrossRef]

50. He, H.; Chen, X.; Sun, C.; Zhang, Y.; Gao, P. Preparation and functional evaluation of oligopeptide-enriched hydrolysate from shrimp (Acetes chinensis) treated with crude protease from Bacillus sp. SM98011. Bioresour. Technol. 2006, 97, 385-390. [CrossRef] [PubMed]

51. Haq, M.; Ho, T.C.; Ahmed, R.; Getachew, A.T.; Cho, Y.-J.; Park, J.-S.; Chun, B.-S. Biofunctional properties of bacterial collagenolytic protease-extracted collagen hydrolysates obtained using catalysts-assisted subcritical water hydrolysis. J. Ind. Eng. Chem. 2020, 81, 332-339. [CrossRef]

52. Yamamoto, S.; Deguchi, K.; Onuma, M.; Numata, N.; Sakai, Y. Absorption and Urinary Excretion of Peptides after Collagen Tripeptide Ingestion in Humans. Biol. Pharm. Bull. 2016, 39, 428-434. [CrossRef] [PubMed]

53. Ahmed, R.; Haq, M.; Chun, B.-S. Characterization of marine derived collagen extracted from the by-products of bigeye tuna (Thunnus obesus). Int. J. Biol. Macromol. 2019, 135, 668-676. [CrossRef] [PubMed]

54. Pratiwi, A.; Hakim, T.R.; Abidin, M.Z.; Fitriyanto, N.A.; Jamhari, J.; Rusman, R.; Erwanto, Y. Angiotensin-converting enzyme inhibitor activity of peptides derived from Kacang goat skin collagen through thermolysin hydrolysis. Vet. World 2021, 14, 161-167. [CrossRef]

55. Blum, M.; Chang, H.Y.; Chuguransky, S.; Grego, T.; Kandasaamy, S.; Mitchell, A.; Nuka, G.; Paysan-Lafosse, T.; Qureshi, M.; Raj, S.; et al. The InterPro protein families and domains database: 20 years on. Nucleic Acids Res. 2021, 49, D344-D354. [CrossRef]

56. Almagro Armenteros, J.J.; Tsirigos, K.D.; Sønderby, C.K.; Petersen, T.N.; Winther, O.; Brunak, S.; von Heijne, G.; Nielsen, H. SignalP 5.0 improves signal peptide predictions using deep neural networks. Nat. Biotechnol. 2019, 37, 420-423. [CrossRef]

57. Thompson, J.D.; Higgins, D.G.; Gibson, T.J. CLUSTAL W: Improving the sensitivity of progressive multiple sequence alignment through sequence weighting, position-specific gap penalties and weight matrix choice. Nucleic Acids Res. 1994, 22, 4673-4680. [CrossRef]

58. Robert, X.; Gouet, P. Deciphering key features in protein structures with the new ENDscript server. Nucleic Acids Res. 2014, 42, W320-W324. [CrossRef] 
59. Bailey, T.L.; Boden, M.; Buske, F.A.; Frith, M.; Grant, C.E.; Clementi, L.; Ren, J.; Li, W.W.; Noble, W.S. MEME SUITE: Tools for motif discovery and searching. Nucleic Acids Res. 2009, 37, W202-W208. [CrossRef]

60. Kumar, S.; Stecher, G.; Li, M.; Knyaz, C.; Tamura, K. MEGA X: Molecular Evolutionary Genetics Analysis across Computing Platforms. Mol. Biol. Evol. 2018, 35, 1547-1549. [CrossRef] [PubMed]

61. Zhao, G.Y.; Chen, X.L.; Zhao, H.L.; Xie, B.B.; Zhou, B.C.; Zhang, Y.Z. Hydrolysis of insoluble collagen by deseasin MCP-01 from deep-sea Pseudoalteromonas sp. SM9913: Collagenolytic characters, collagen-binding ability of C-terminal polycystic kidney disease domain, and implication for its novel role in deep-sea sedimentary particulate organic nitrogen degradation. J. Biol. Chem. 2008, 283, 36100-36107. [CrossRef] [PubMed]

62. Yemm, E.W.; Cocking, E.C.; Ricketts, R.E. The determination of amino-acids with ninhydrin. Analyst 1955, 80, 209-214. [CrossRef]

63. He, H.L.; Chen, X.L.; Li, J.W.; Zhang, Y.Z.; Gao, P.J. Taste improvement of refrigerated meat treated with cold-adapted Protease. Food Chem. 2004, 84, 307-311. [CrossRef]

64. Chen, X.L.; Xie, B.B.; Bian, F.; Zhao, G.Y.; Zhao, H.L.; He, H.L.; Zhou, B.C.; Zhang, Y.Z. Ecological function of myroilysin, a novel bacterial M12 metalloprotease with elastinolytic activity and a synergistic role in collagen hydrolysis, in biodegradation of deep-sea high-molecular-weight organic nitrogen. Appl. Environ. Microbiol. 2009, 75, 1838-1844. [CrossRef]

65. Sun, M.L.; Zhao, F.; Shi, M.; Zhang, X.Y.; Zhou, B.C.; Zhang, Y.Z.; Chen, X.L. Characterization and Biotechnological Potential Analysis of a New Exopolysaccharide from the Arctic Marine Bacterium Polaribacter sp. SM1127. Sci. Rep. 2015, 5 , 18435. [CrossRef] 